\title{
Effect of Pilates Exercises on Kidney Functions in Patients with Hypertension
}

\author{
ZEINAB E. IBRAHIM, M.Sc.*; NESREEN G. ELNAHASS, Ph.D.**; HEBA A. ABDEEN, Ph.D.** and \\ SALLY ADEL HAKIM, M.D.*** \\ The Department of Physical Therapy for Cardiovascular/Respiratory Disorders \& Geriatrics, \\ Physiotherapist at El-Santa Central Hospital*, Physical Therapy for Cardiovascular/Respiratory Disorders \& Geriatrics, \\ Faculty of Physical Therapy, Cairo University** and Department of Public Health, Faculty of Medicine, Ain Shams University***
}

\begin{abstract}
Background: The Pilates method is a conditioning program in hypertensive patients of the body and mind that is gaining in popularity and acceptance worldwide.

Aim of Study: To determine the response of kidney functions after pilates exercise in patients with hypertension.

Material and Methods: Fifty Patients of both sexes were recruited from El-Santa Central Hospital, their ages ranged from 40 to 50 years. All of them suffered from hypertension form 5-10 years ago moderate stage systolic $(160-179 \mathrm{mmHg})$ diastolic $(100-109 \mathrm{mmHg})$ to severe stage systolic $(180-209$ $\mathrm{mmHg}$ ) diastolic (110-1 19mmHg) according to Joint National Committee (JNC-V) classification. The study was pre-post study, were all the patients performed 5 pilates exercises per session for 3 sessions per week for a whole study duration of 8 weeks we measure kidney function tests (urea-creatinine) and blood pressure (systolic and diastolic).
\end{abstract}

Results: The statistical analysis by paired $t$-test revealed that there was significant difference $(p=0.001 ; p<0.05)$ between pre- and post-systolic blood pressure within study group, the mean values of pre- and post-diastolic blood pressure were $100 \pm 8.32$ and $95 \pm 8.02$, respectively, with improvement percentage $5.00 \%$. The statistical analysis by paired $t$-test revealed that there was significant difference $(p=0.001 ; p<0.05)$ between pre- and post-diastolic blood pressure within study group, the mean values of pre- and post-creatinine were $1.76 \pm 1.12$ and $1.69 \pm 1.10$, respectively, with improvement percentage $3.98 \%$. The statistical analysis by paired $t$-test revealed that there was no significant difference $(p=0.083 ; p>0.05)$ between pre- and post-creatinine within study group, The mean values of preand post-urea were $61.09 \pm 6.40$ and $58.93 \pm 6.31$, respectively, with improvement percentage $3.54 \%$. The statistical analysis by paired $t$-test revealed that there was no significant difference ( $p=0.068 ; p>0.05)$ between pre- and post-urea within study group.

Conclusion: Pilates exercises have a statistically significant effect on blood pressure but not on kidney functions in patients with hypertension.

Correspondence to: Dr. Zeinab E. Ibrahim, The Department of Physical Therapy for Cardiovascular/Respiratory Disorders \& Geriatrics, Physiotherapist at El-Santa Central Hospital
Key Words: Pilates exercises - Hypertension - Kidney functions.

\section{Introduction}

HYPERTENSION is defined as a measured blood pressure of $140 / 90 \mathrm{~mm} \mathrm{Hg}$ or greater or reported use of antihypertensive medications [1] .

Hypertension is the most common preventable risk factor for cardiovascular disease (CVD; including coronary heart disease, heart failure, stroke, myocardial infarction, atrial fibrillation and peripheral artery disease), chronic kidney disease (CKD) and cognitive impairment, and is the leading single contributor to all-cause death and disability worldwide [2].

Low intensity physical activity (e.g., Pilates) has a favorable prognostic effect on individuals who cannot meet the recommended criteria of moderate physical activity because the dose response relationship between fitness and cardiovascular and/or cardio metabolic risk is still undergoing debate [3]. The Pilates method is a conditioning program of the body and mind that is gaining in popularity and acceptance worldwide [4]. The method has been characterized as a non repetitive and strenuous exercise that can suit the needs of each individual. The exercise program incorporates the use of special apparatus and equipment, with movements that allow, among other benefits, improvements in flexibility, strength, coordination, blood circulation, fitness, range of motion, and postural alignment [5].

It is a method of resistance training that works with low-impact muscle exercises that are based 
on isometric exercises for the abdominal muscles that generate force without motion and stabilize the spine [6].

Practice of pilates showed an improvement in body composition in healthy people, as well as a reduction in risk factors and cardiovascular mortality [7].

\section{Aim of the study:}

This study aims to determine the effect of Pilates exercises on kidney functions in patients with hypertension.

\section{Patients and Methods}

The study is a pre-post study.

\section{Patients:}

Fifty Patients of both sexes were recruited from El-Santa Central Hospital, their ages ranged from 40 to 50 years. This study was conducted from March 2020 to December 2020. All patients suffered from hypertension moderate stage systolic $(160-179 \mathrm{mmHg})$ diastolic $(100-109 \mathrm{mmHg})$ to sever stage systolic (180-209mmHg) diastolic (110-119 $\mathrm{mmHg}$ ) to JNC-V classification [8].

\section{Ethical consideration:}

Ethical committee for the study was approved from the faculty of physical therapy, Cairo University. The nature, the procedures and risks of the study was explained to all patients and a consent form was signed by each patient.

\section{Inclusion criteria:}

Both sexes with hypertension include the following:

1- The patient ages ranged from 40 to 50 years

2- Moderate systolic $(160-179 \mathrm{mmHg})$ diastolic (100-109mmHg) to sever hypertensive patient systolic $(180-209 \mathrm{mmHg})$ diastolic $(110-119 \mathrm{~mm}-$ $\mathrm{Hg}$ ). They were complained 5-10 years ago form hypertension they take medications (beta blockers - vasodilator - diuretics).

\section{Exclusion criteria:}

1- Patients who have neuropathy issues.

2- Rheumatic and orthopedic diseases.

3- Patients with recent abdominal surgery.

4- Active smokers.

5- Patients with chronic hepatitis.

6- Patients with pacemaker.

\section{Materials:}

Evaluation equipment and techniques:

1- Weight and height scale: This scale was used for measuring weight and height of each patient to calculate body mass index (BMI) $\left(\mathrm{Kg} / \mathrm{m}^{2}\right)$ which was calculated using the following formula: $\mathrm{BMI}=$ weight $(\mathrm{kg}) /$ height $\left(\mathrm{m}^{2}\right)$ [9]

2- Sphygmomanometer: To measure blood pressure (systolic and diastolic).

3- Kidney function test: For measuring levels of urea and creatine in plasma.

4- Borg scale: Ratings of perceived exertion are generally believed to be valid and reliable markers of physiological intensity during exercise and are recommended to monitor exercise intensity [10]. The Rating of Perceived Exertion (RPE) scale is based on a range between 6 and 20 , with 6 being the least amount of exertion and 20 being the maximum level of exertion [25].

\section{Procedures:}

1- The first contact with the patients allows them to complete the demographic evaluation form.

2- Kidney function test, blood pressure and BMI were evaluated before the study and at the end of 8 weeks of the study.

\section{Training procedures:}

At beginning of each exercise session, if the patient had any symptoms that prevent exercises performance, the session was canceled. After beginning of session, break criteria were considered in the following circumstances; incidence of intense physical tiredness, chest pain, dizziness, paleness, syncope, pre-syncope, dyspnea disproportionate to effort intensity, arrhythmia and hypotension or hypertensive response. When any of these symptoms will be detected, patient will be transferred for medical evaluation.

Initially, an interview was conducted with patient, to collect data as previous and current history, co-morbidities, medications, postural changes, vital signs.

Pilates exercises: Aiming to allow the practitioner to move consciously without pain and fatigue, the method is based on 6 principles $[13,17]$ (1) Breathing, (2) Control, (3) Concentration, (4) Centering, (5) Precision, and (6) Fluidity of movement. The exercises should be performed slowly and smoothly, allowing the practitioner to achieve flexibility and strength and requiring a great deal of concentration, thus demanding high levels of body awareness [12]. 


\section{The pilates training included:}

\section{1- Pelvic curl:}

- Each patient was asked to raise his pelvic up to be straight with his chest.

- Then he was asked to relax and breath in this position and remember to relax shoulders and consciously release any tension in the upper body.

- Further he was asked to hold for 5 breaths and slowly lay down to the original position.

- This exercise was repeated 10 times in each session.

\section{2- Supine spine twist:}

- From long sitting position the patient twisted his spine to the left and to the right with his arm abducted

- He repeated the exercise 10 times per session.

\section{3- Roll up exercise:}

- Each patient was asked to lay flat on his back in crook lying position with placing hands on above his hip.

- The patient was asked to exhale raising to a sitting position with touching his knees with arms and focus on tightening his stomach.

- The patient was asked to inhale bringing his shoulders to the floor.

- The patient was asked to repeat exercise 10 times per session.

\section{4- Leg circles exercise:}

- From side lying position, the patient was asked to abduct his uppermost lower limb and draw circles in the air 10 times.

\section{5- Rolling like a ball exercise:}

- The patient was asked to hug his legs toward his chest and roll like a ball.

- The patient repeated exercise 10 times in each session.

\section{Data collection:}

Data were screened, for normality assumption test and homogeneity of variance. Normality test of data using Shapiro-Wilk test was used, that reflect the data was normally distributed after removal outliers that detected by box and whiskers plots. All these findings allowed the researchers to conduct parametric and non-parametric analysis. Additionally, testing for the homogeneity of variance revealed that there was no significant difference $(p>0.05)$.

\section{Statistical analysis:}

The statistical analysis was conducted by using statistical SPSS Package program version 20 for Windows (SPSS, Inc., Chicago, IL). The following statistical procedures were conducted:

- Descriptive statistics including the mean and standard deviation for physical characteristic (weight, height, BMI), blood pressure (systolic and diastolic), creatinine and urea variables.

- Paired $t$-test to compare between pre and posttreatment within study group for blood pressure (systolic and diastolic), creatinine and urea variables.

- Significant level: All statistical analyses were significant at 0.05 level of probability $(p \leq 0.05)$.

\section{Results}

\section{1-Physical characteristic:}

Represented the weight, height, and BMI values in study group. Mean values of weight, height, and BMI were $103.70 \pm 15.10 \mathrm{~kg}, 168.15 \pm 673 \mathrm{~cm}$, and $36.76 \pm 5.97 \mathrm{~kg} / \mathrm{m}^{2}$, respectively in study group.

\section{2-Blood pressure:}

\section{Systolic blood pressure:}

Represented the comparative mean values between pre- and post-systolic blood pressure in study group. The mean values of pre- and postsystolic blood pressure were $170 \pm 16.31$ and $163 \pm 16.94$, respectively, with improvement percentage $4.12 \%$. The statistical analysis by paired $t$-test revealed that there was significant difference $(p=0.001 ; p<0.05)$ between pre- and post-systolic blood pressure within study group.

\section{Diastolic blood pressure:}

Represented the comparative mean values between pre- and post- diastolic blood pressure in study group. The mean values of pre- and postdiastolic blood pressure were $100 \pm 8.32$ and $95 \pm 8.02$, respectively, with improvement percentage $5.00 \%$. The statistical analysis by paired $t$-test revealed that there was significant difference $(p=0.001 ; p<0.05)$ between pre- and post-diastolic blood pressure within study group.

\section{3- Creatinine:}

Represented the comparative mean values between pre- and post-creatinine in study group. The mean values of pre- and post-creatinine were $1.76 \pm 1.12$ and $1.69 \pm 1.10$, respectively, with improvement percentage $3.98 \%$. The statistical analysis by paired $t$-test revealed that there was no 
significant difference $(p=0.083 ; p>0.05)$ between pre- and post-creatinine within study group.

\section{4- Urea:}

Represented the comparative mean values between pre- and post-urea in study group. The mean values of pre- and post-urea were $61.09 \pm 6.40$ and $58.93 \pm 6.31$, respectively, with improvement percentage $3.54 \%$. The statistical analysis by paired $t$-test revealed that there was no significant difference $(p=0.068 ; p>0.05)$ between pre- and posturea within study group.

Table (1): Comparison between pre- and post-treatment of all outcomes variables in study group.

\begin{tabular}{|c|c|c|c|c|c|}
\hline \multirow{2}{*}{ Variables } & \multicolumn{2}{|c|}{ Treatments (Mean \pm SD) } & \multirow{2}{*}{ Mean difference } & \multirow{2}{*}{ Improvement \% } & \multirow{2}{*}{$p$-value } \\
\hline & Pre-treatment & Post-treatment & & & \\
\hline Systolic blood pressure & $170 \pm 16.31$ & $163 \pm 16.94$ & 7.00 & $4.12 \%$ & $0.001 *$ \\
\hline Diastolic blood pressure & $100 \pm 8.32$ & $95 \pm 8.02$ & 5.00 & $5.00 \%$ & $0.001 *$ \\
\hline Creatinine & $1.76 \pm 1.12$ & $1.69 \pm 1.10$ & 0.07 & $3.97 \%$ & 0.083 \\
\hline Urea & $61.09 \pm 6.40$ & $58.93 \pm 6.31$ & 2.16 & $3.54 \%$ & 0.068 \\
\hline
\end{tabular}

Data are expressed as mean \pm standard deviation (SD). $\quad p$-value: Probability value. * Significant $(p<0.05)$

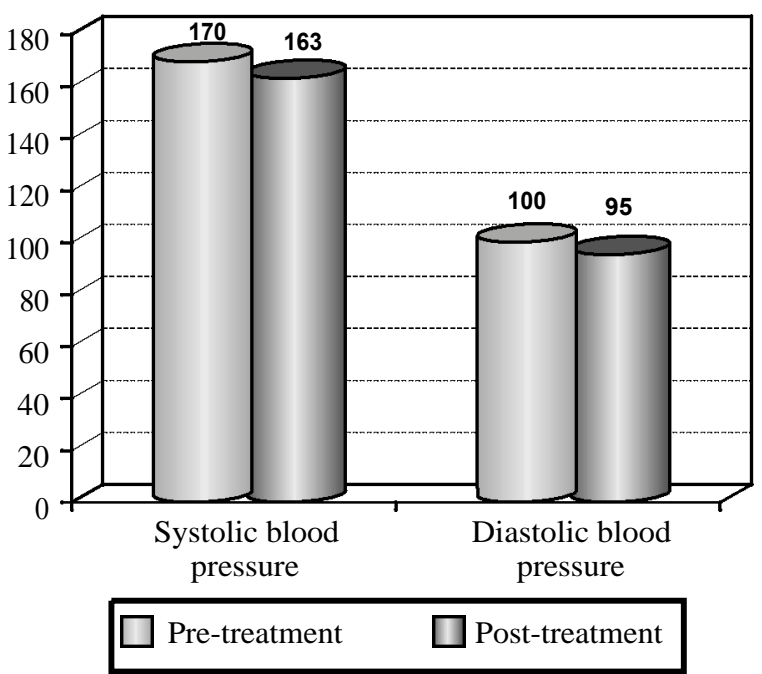

Fig. (1): Comparison between pre and post treatment of systolic blood pressure and diastolic blood pressure.

\section{Discussion}

The current study was designed to investigate the effect of Pilates exercises on kidney functions in patients with hypertension.

The practical part was conducted in the outpatient clinic of El-Santa Central Hospital. Fifty patients were selected randomly and received 5 pilates exercises per session for 3 sessions per week for 8 weeks. Blood pressure and kidney function tests were measured before and after treatment. Results showed statistically significant differences $(p=0.001 ; p<0.05)$ between pre- and post- systolic and diastolic blood pressure. But there were no statistically significant differences between pre- and post-values of creatinine $(p=0.083 ; p>0.05)$ and urea $(p=0.068 ; p>0.05)$. So, it could be concluded that Pilates exercises have

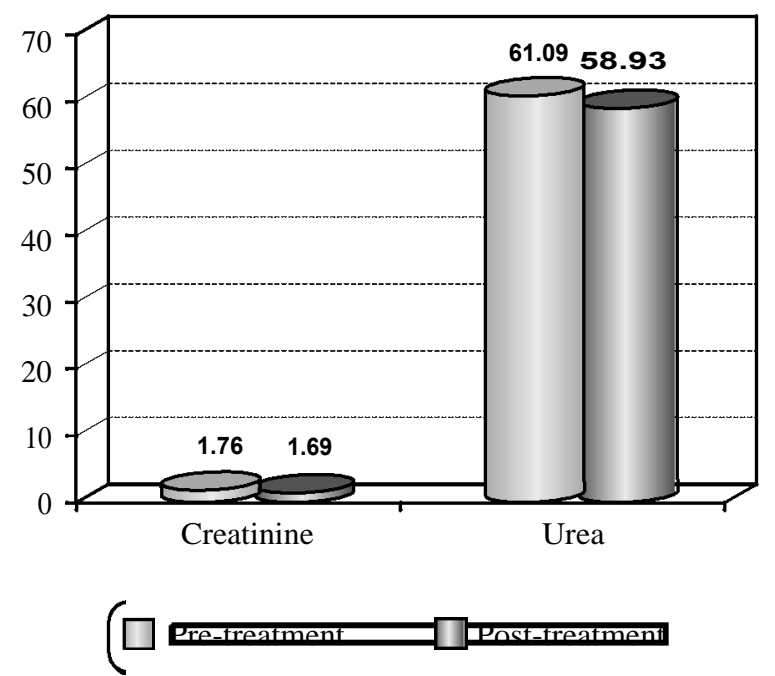

Fig. (2): Comparison between pre and post treatment of creatinine and Urea.

a statistically significant effect on blood pressure but not on kidney functions in patients with hypertension.

An important aspect of Pilates is the fact that the method emphasizes breath as a prime factor, in which the fulfillment of all exercises must be associated with an adequate and continuous breathing that prevents the performance of the Valsalva maneuver $[\mathbf{1 2}, \mathbf{1 3}]$. The expiratory phase is also characterized by contraction of the transversus abdominis muscles that are associated with contraction of the multifidus muscles and the pelvic floor [12]. As a result, the abdominal muscles are worked intensely during the exercise $[\mathbf{1 4 , 1 5 , 1 6 ]}$. The Pilates method has been found to prevent the Valsalva maneuver because the activities in Pilates require constant airflow at all stages of movement [17]. 
Randomized, controlled clinical trial using Pilates Mat was conducted among 44 hypertensive women, with a mean age of 50 years. That study showed significant results after a training period of 16 weeks with Pilates Mat. At the end of 32 sessions, the group that received training showed significant decreases in the systolic and diastolic pressures, within and between groups, when compared with a control group that received no intervention [18]. In addition, it is important to note the influence of the respiratory cycle in the hemodynamic responses of the BP to the exercise training in hypertensive individuals [19]. In general, the BP values observed during the execution of exercises for strength are influenced by the adopted breathing pattern. An incorrect breathing pattern can result in the blockage of ventilation in the active phase of the movement. That blockage can create internal pressure gradients, causing increased cardiac work that results in an exaggerated increase in BP, increased intrathoracic pressure, and decreased venous return. Those factors can contribute to an increased cardiovascular risk during exercise with weights in hypertensive patients [19]

Results coincided with this study was designed to investigate the blood pressure (BP) and heart rate variability (HRV) responses to a single session of Pilates among adults with hypertension. It was conclude that a single session of Pilates reduced $\mathrm{BP}$ by $5-8 \mathrm{~mm} \mathrm{Hg}$ in adults with hypertension during the first 60 minutes of post-exercise recovery. Acute BP reduction was concomitant to lowered cardiac parasympathetic activity. Those findings were promising for the use of Pilates as an alternative exercise modality to lower BP [20].

The eight-week pilates exercise reduced blood pressure and resting heart rate and increased the production of nitric oxide in elderly men. So, it seems that the regular physical exercise can be effective as a preventive factor in the outbreak of cardiovascular diseases of the elderly men and that results came in agreement with the findings of the current study [21].

Results supported by another study that it was found that both vitamin D supplemen-tation and Pilates training interventions for overweight men may lead to an improvement in the renal function of overweight individuals with abnormal vitamin D status by increasing glomerular filtration rate (GFR) and decreasing urea, uric acid, and creatinine levels. Nonetheless, the combined intervention is associated with stronger effects [22]

On the other hand; Sarmento et al., concluded that both conventional physical therapy and Pilates, showed improvements and there is no difference between them. Therefore both can be used in chronic renal patients [23]

Another study designed to determine the effects of mat Pilates on resting heart rate, resting blood pressure and fasting blood glucose, cholesterol and triglycerides in elderly women. It was concluded that it is difficult to establish a case for using Pilates as a substitute for more conventional forms of exercising when exclusively attempting to favorably alter cardiometabolic parameters at least among the elderly women and that results came in partial agreement as systolic only improved but in the current study the systolic and diastolic improved [24].

\section{Conclusion:}

It is concluded that pilates exercise program could have a positive effect on reducing blood pressure in hypertensive patients, however no effects were shown in regards to kidney functions.

\section{References}

1- MARTINS MENESES D.T., ANTUNES H.K., OLIVEIRA N.R. and MEDEIROS A.: Mat Pilates training reduced clinical and ambulatory blood pressure in hypertensive women using antihypertensive medications. Int. J. Cardiol., 179: 262-8, 2014.

2- FOROUZANFAR M.H., AFSHIN A., ALEXANDER L.T., ANDERSON H.R., BHUTTA Z.A., BIRYUKOV S. and CARRERO J.J.: Global, regional, and national comparative risk assessment of 79 behavioural, environmental and occupational, and metabolic risks or clusters of risks, 1990-2015: A systematic analysis for the Global Burden of Disease Study 2015. The Lancet, 388 (10053): 16591724, 2016.

3- PERK J., De BACKER G., GOHLKE H., GRAHAM I., REINER Z., VERSCHUREN M. and ZANNAD F.: ESC Committee for Practice Guidelines (CPG) European Guidelines on cardiovascular disease prevention in clinical practice (version 2012). Eur. Heart J., 33 (13): 1635-1701, 2012.

4- SOUZA M.S. and VIEIRA C.B.: Who are the people looking for the Pilates method? J. Bodywork Movement Ther., 10: 328-334, 2006.

5- MUSCOLINO J.E. and CIPRIANI S.: Pilates and the "powerhouse"-I. Journal of bodywork and movement therapies, 8 (1): 15-24, 2004.

6- GÃ3MEZ V.S., GARCÃ-A O.G. and EJERCICIO FÃSICO Y. PILATES DURANTE EL EMBARAZO: Revista Digital, Buenos Aires, 14: 136, 2009. MarÃ@s G., Mares K.B., A import $\tilde{A} \notin$ ncia da estabiliza $\tilde{A} \S \tilde{A} £ o$ central no m $\tilde{A} \odot$ todo Pilates: uma revis $\tilde{A} £$ o sistem $\tilde{A}_{i}$ tica. Fisioter Mov., 25 (2): 445-451, 2012.

7- RUIZ-MONTERO P.J., CASTILLO-RODRIGUEZ A., MIKALAC KI M., NEBOJSA C. \& KOROVLJEV D.: 24weeks Pilates-aerobic and educative training to improve 
body fat mass in elderly Serbian women. Clinical interventions in aging, 9: 243, 2014.

8- LOPEZ A.D., MATHERS C.D., EZZATI M., JAMISON D.T. and MURRAY C.J.: Global and regional burden of disease and risk factors: Systematic analysis of population health data. Lancet., 367: 1747-1757, 2006.

9- World Health Organization: "Appropriate body-mass index for Asian populations and its complications for policy and intervention strategies", World health organization expert consultation, The Lancet, 157-163. J. Photobiol., 70 (1): 39-44, 2004.

10- JANICE J., KELLY S., ANDREW S., MARIA C. and KATHERINE E.: "Functional walk tests in individuals with stroke: Relation to perceived exertion and myocardial exertion", Stroke, 33: 756, 2002.

11-Gil A. and Novaes J.: Core \& Training: Pilates, plataforma vibratória, treinamento funcional. Editora Ícone, 344, 2014.

12- PIRES D.C. and SÁ C.K.: Pilates: Notas sobre aspectos históricos, princípios, técnicas e aplicações. Revista Digital, Buenos Aires, 10: 91, 2005.

13- MARIN M.N.: Pilates en la escuela. Revista Digital, Buenos Aires, 14: 132, 2009.

14- CRITCHLEY D.J., PIERSON Z. and BATTERSBY G.: Effect of Pilates mat exercises and conventional exercise programmers on transversus abdominis and obliquus internus abdominis activity: Pilot randomized trial. Man Ther., 16 (2): 183-189, 2011.

15- SILVA M.F., SILVA M.A.C., CAMPOS R.R.D., OBARA K., MOSTAGI F.Q.R.C., CARDOSO A.P.R.G. and CARDOSO J.R.: A comparative analysis of the electrical activity of the abdominal muscles during traditional and Pilates-based exercises under two conditions. Revista Brasileira de Cineantropometria \& Desempenho Humano, 15 (3): 296-304, 2013.

16- JAGO R., JONKER M.L., MISSAGHIAN M. and BARANOWSKI T.: Effect of 4 weeks of Pilates on the body composition of young girls. Preventive Medicine, 42 (3): 177-180, 2006.
17- PIRES D.C. and SÁ C.K.: Pilates: Notas sobre aspectos históricos, princípios, técnicas e aplicações. Revista Digital, Buenos Aires, 10: 91, 2005.

18- MARTINS-MENESES D., HANNA H.K. and de OLIVEIRA N.R.: Mat Pilates training reduced clinical and ambulatory blood pressure in hypertensive women using antihypertensive medications. Int. J. Cardiol. January, 179: 2620-268, 2015.

19- GOTSHALL R.W., GOOTMAN J., BYRNES W.C., FLECK S.J. and VALOVICH T.C.: Noninvasive characterization of the blood pressure response to the doubleleg press exercise. Journal of Exercise Physiology Online, 4 (3), 2001.

20- ROCHA J., CUNHA F.A., CORDEIRO R., MONTEIRO W., PESCATELLO L.S. and FARINATTI P.: Acute effect of a single session of pilates on blood pressure and cardiac autonomic control in middle-aged adults with hypertension. The Journal of Strength \& Conditioning Research, 34 (1): 114-123, 2020.

21- EGHBALI F. and MORADI M.: The effect of a course of pilates exercise on hypertension, nitric oxide, and resting heart rate in the eldrly men with hypertension. Arak Med. Univ. J., 19 (11): 1-10, 2017.

22- NEMATI CHERATI B. and HABIBIAN M.: Possible Effect of Pilates Exercises and Vitamin D on Renal Function Parameters in Overweight Men: A Randomized Clinical Trial. Qom University of Medical Sciences Journal, 14 (7): 1-11, 2020.

23- SARMENTO L.A., PINTO J.S., da SILVA A.P., CABRAL C.M. and CHIAVEGATO L.D.: Effect of conventional physical therapy and Pilates in functionality, respiratory muscle strength and ability to exercise in hospitalized chronic renal patients: A randomized controlled trial. Clinical rehabilitation, 31 (4): 508-520, 2017.

24- SHAW I., SHAW B.S. and TER GOON D.: Effects of a mat pilates program on cardiometabolic parameters in elderly women, 2013.

25- WILLIAMS N.: The Borg Rating of Perceived Exertion (RPE) scale. Occup. Med., 67 (5): 404-405, 2017. 


\section{تأ ثير تمارين البيلاتس على وظائف الكلى

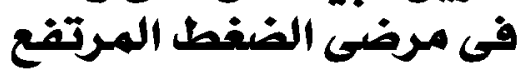

الخلفية:طريقة بيلاتيس هى برنامج تكيف لمرضى ارتفاع ضفط الدم من الجسم والعقل الذى يكسب شعبية ويقبل فى جميع أنحاء العالم. الغرض : تحديد استجابة وظائف الكلى بعد ممارسة تمارين البيلاتيس فى المرضى المصابين بارتفاع ضغط الدم.

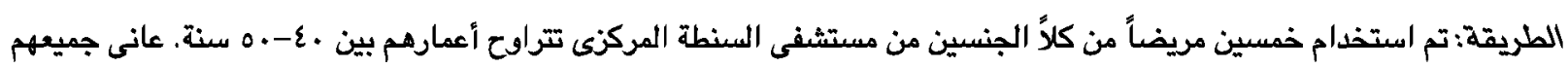

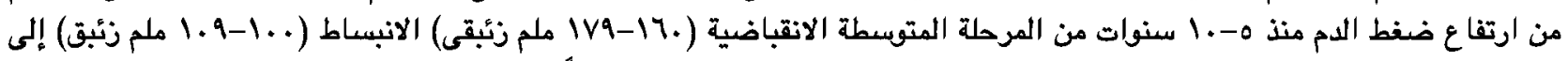

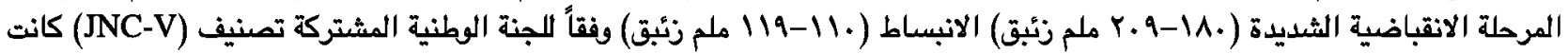

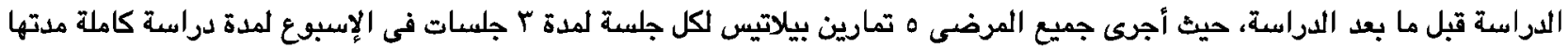
A أسابيع نقوم بقياس اختبارات وظائف الكى (اليوريا والكرياتينين) وضغط الدين الد م (الانقباضيى والانبساطى).

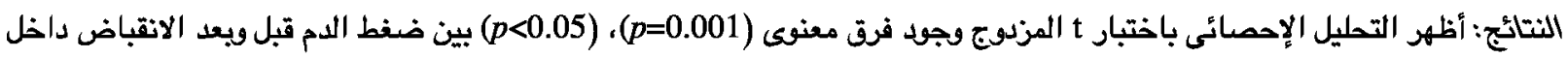

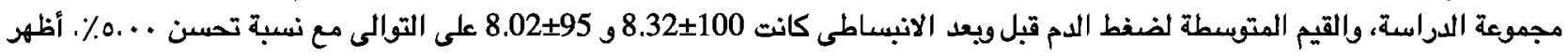

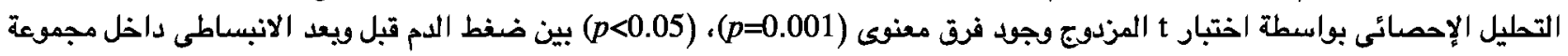

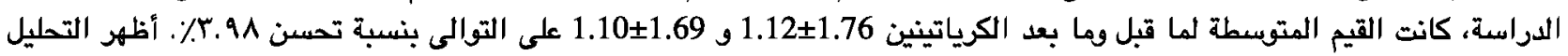

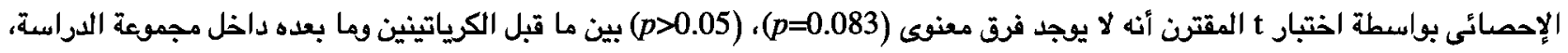

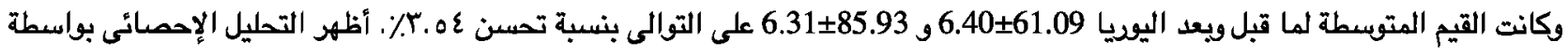

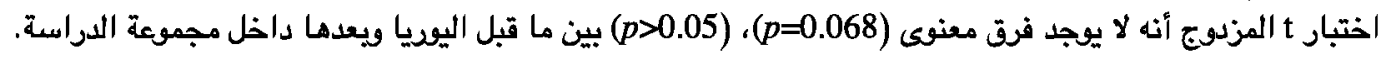
الخلاصة: تمارين البيلاتيس لها تأثير هام إحصائياً على ضفط الدم ولكن ليس على وظائف الكلى فى مرضى ارتفاع ضفط الدم. 